\title{
Patient with ovarian insufficiency: baby born after anticancer therapy and re- transplantation of cryopreserved ovarian tissue
}

Vladimir Isachenko ${ }^{1 *} \mathbb{D}$, Bernd Morgenstern ${ }^{1}$, Plamen Todorov², Evgenia Isachenko ${ }^{1}$, Peter Mallmann', Bettina Hanstein ${ }^{1}$ and Gohar Rahimi ${ }^{1}$

\begin{abstract}
Background: The second major cause of death is cancer. In fact, the effectiveness of anticancer treatments and positive long-term prognosis for young women has increased. However, the problem of post-cancer infertility plays a significant role, because chemotherapy can be gonadotoxic and lead to the functional death of ovaries. There is potential key solution to this problem: cryopreservation of ovarian tissue before cancer therapy with re-implantation after convalescence. Data regarding cryopreservation and re-transplantation of ovarian tissue from patients with ovarian insufficiency is limited. The aim of this treatment was the re-transplantation of cryopreserved ovarian tissue after anticancer therapy of patient with ovarian insufficiency (56 IU/I FSH, $8 \mathrm{ng} / \mathrm{l} \beta$-estradiol, $<1.1 \mathrm{ng} / \mathrm{ml}$ antiMullerian hormone, 1 primary follicle per $10 \mathrm{~mm}^{3}$ ).

Case presentation: After the operation, four tissue fragments $(10-16 \times 8-13 \times 1.0-1.2 \mathrm{~mm})$ were cooled to $5^{\circ} \mathrm{C}$ in the freezing medium (culture medium $+6 \%$ ethylene glycol $+6 \%$ dimethyl sulfoxide $+0.15 \mathrm{M}$ sucrose) for $24 \mathrm{~h}$, frozen and thawed. Freezing was performed in four standard $5 \mathrm{ml}$ cryo-vials with ice formation at $-9^{\circ} \mathrm{C}$, cooling from -9 to $-34^{\circ} \mathrm{C}$ at a rate of $-0.3^{\circ} \mathrm{C} / \mathrm{min}$ and plunging at $-34^{\circ} \mathrm{C}$ into liquid nitrogen. After thawing in a $100^{\circ} \mathrm{C}$ (boiling) water bath, the removal of cryoprotectants was performed in $0.5 \mathrm{M}$ sucrose with $20 \mathrm{~min}$. exposure in sucrose and 30 min. stepping rehydration. After thawing of one cryo-vial, part $\left(5 \mathrm{~mm}^{3}\right)$ of experimental ovarian tissue after 7 day in vitro culture was histological evaluated and two ovarian fragments $(8 \times 7 \times 1.0 \mathrm{~mm}$ and $7 \times 6 \times 1.0 \mathrm{~mm})$ were retransplanted. The quantity of follicles after cryopreservation and in vitro culture was not increased $(P>0.1)$ : it was found 1 primordial follicle in $5 \mathrm{~mm}^{3}$ of tissue. Thirty seven days after the re-transplantation of ovarian tissue, the restoration of the menstrual cycle of Patient $\mathrm{W}$. was noted. Three months after the transplantation, the patient became spontaneously pregnant and delivered a healthy baby girl at term.
\end{abstract}

Conclusions: Described protocol of conventional cryopreservation of ovarian tissue can be used for treatment of patients with ovarian insufficiency.

Keywords: Baby born, Cancer, Cryopreservation, Cryoprotectants, Human ovarian tissue, Re-transplantation

\footnotetext{
* Correspondence: vladimir.isachenko@gmail.com

'Department of Obstetrics and Genecology, University Maternal Hospital, Research Group for Reproductive Medicine and IVF-Laboratory, Cologne University, Cologne, Germany

Full list of author information is available at the end of the article
}

(c) The Author(s). 2020 Open Access This article is licensed under a Creative Commons Attribution 4.0 International License, which permits use, sharing, adaptation, distribution and reproduction in any medium or format, as long as you give appropriate credit to the original author(s) and the source, provide a link to the Creative Commons licence, and indicate if changes were made. The images or other third party material in this article are included in the article's Creative Commons licence, unless indicated otherwise in a credit line to the material. If material is not included in the article's Creative Commons licence and your intended use is not permitted by statutory regulation or exceeds the permitted use, you will need to obtain permission directly from the copyright holder. To view a copy of this licence, visit http://creativecommons.org/licenses/by/4.0/ The Creative Commons Public Domain Dedication waiver (http://creativecommons.org/publicdomain/zero/1.0/) applies to the data made available in this article, unless otherwise stated in a credit line to the data. 


\section{Background}

The second major cause of death is cancer [1]. In fact, the effectiveness of anticancer treatments and positive long-term prognosis for young women has increased. However, the problem of post-cancer infertility plays a significant role, because chemotherapy can be gonadotoxic and lead to the functional death of ovaries. There is potential key solution to this problem: cryopreservation of ovarian tissue before cancer therapy with reimplantation after convalescence [2]. Now this procedure is a routine: more than 130 live births from cryopreserved ovarian tissue have been reported worldwide as of June 2017 [3]. However, the data regarding cryopreservation and re-transplantation of ovarian tissue of patients with ovarian insufficiency is limited.

The aim of this treatment was the re-transplantation of cryopreserved ovarian tissue after anticancer therapy of patient with ovarian insufficiency (56 IU/l FSH, $8 \mathrm{ng} / \mathrm{l}$ $\beta$-estradiol, $<1.1 \mathrm{ng} / \mathrm{ml}$ anti-Müllerian hormone, 1 primary follicle per $10 \mathrm{~mm}^{3}$ ).

\section{Case presentation}

This study was approved by the Ethics Boards of University Cologne (applications 99,184 and 13-147). Written informed consents were obtained from participant involved in our study.

Except where otherwise stated, all chemicals were obtained from Sigma (Sigma Chemical Co., St. Louis, MO, USA).

\section{Design of investigations}

Two series of investigations were carried out. First series of experiments included thawing and re-transplantation of ovarian tissue. Experiments of second series were performed on the day of thawing and re-transplantation. It was evaluated the quantity of follicles in thawed ovarian tissue.

Tissue collection, dissection, pre-cooling, cryopreservation (freezing and thawing) and in vitro culture

The medium used for transport and dissection, the culture (basal) medium, was comprised of Leibovitz L-15 with 5\% Dextran Serum Substitute (Irvine Sci., Santa Ana, CA, USA). After removal of whole left ovary, this ovary was kept at a temperature of 32 to $34{ }^{\circ} \mathrm{C}$, and then was transported to the laboratory within $10 \mathrm{~min}$ of surgery. Using tweezers and a No. 22 scalpel, the ovary was dissected into four medulla-contained fragments. Parallel with cryopreservation of four large fragments for following clinical transplantation, 10 small pieces $(1.0 \times 1.0 \times$ $1.0 \mathrm{~mm}$ ) were been frozen for following evaluation of follicles after thawing. In accordance with SOP protocol of our clinic, on the day of operation $10 \mathrm{~mm}^{3}$ of fresh ovarian tissue was evaluated for detection of follicles.
Then, the large fragments and experimental pieces were cooled at $5{ }^{\circ} \mathrm{C}$ for $24 \mathrm{~h}$ in the freezing medium (basal medium $+6 \%(\mathrm{v} / \mathrm{v})$ ethylene glycol $+6 \%(\mathrm{v} / \mathrm{v})$ dimethyl sulfoxide $+0.15 \mathrm{M}$ sucrose). Four ovarian fragments and 10 small pieces were frozen the next day as described below.

The procedure of freezing and thawing was performed as published previously [4-10]. Pre-cooling of the ovarian tissue was performed in the presence of cryoprotectants (in the freezing medium) as described earlier [11]. The freezing medium composed of the culture medium supplemented with freezing solution. Freezing was performed in standard $5 \mathrm{ml}$ cryo-vials with ice formation at $-9{ }^{\circ} \mathrm{C}$, cooling from -9 to $-34{ }^{\circ} \mathrm{C}$ at a rate of $-0.3{ }^{\circ} \mathrm{C} /$ min and plunging at $-34^{\circ} \mathrm{C}$ into liquid nitrogen. Sixteen seconds thawing was performed in a $100{ }^{\circ} \mathrm{C}$ (boiling) water bath as described earlier $[6,8,12]$. The removal of cryoprotectants was performed in $0.5 \mathrm{M}$ sucrose [8] with $20 \mathrm{~min}$. exposure in sucrose and $30 \mathrm{~min}$. stepping rehydration. The last step involved three washes in basal medium for $10 \mathrm{~min}$. immediately prior to placement for in vitro culture or for transplantation into the patient.

In vitro culture of tissue was performed as described earlier [6], with some modifications. Ovarian tissue pieces were transferred to $700 \mathrm{ml}$ dishes for suspension culture (Cellstar ${ }^{\mathrm{TM}}$, Greiner Bio-One $\mathrm{GmbH}$ ) in $100 \mathrm{ml}$ AIM-V ${ }^{\mathrm{TM}}$ medium for tissue culture (Gibco, Grand Island, NY, USA) and cultured for 7 days in vitro in air at $37^{\circ} \mathrm{C}$ in $5 \% \mathrm{CO}_{2}$, with agitation at $75 \mathrm{osc} / \mathrm{min}$ using a rotating orbital shaker (N-Biotek, Bucheon, Korea). Five ovarian pieces were cultured in one culture dish. After the culture, histological evaluation of tissue was performed. Examples of normality of follicles and of the different follicular degenerations can be observed elsewhere [7, 9].

Experiments of second series were performed on the day of thawing and re-transplantation of ovarian tissue. It was evaluated the quantity and quality of follicles in frozen and thawed ovarian tissue.

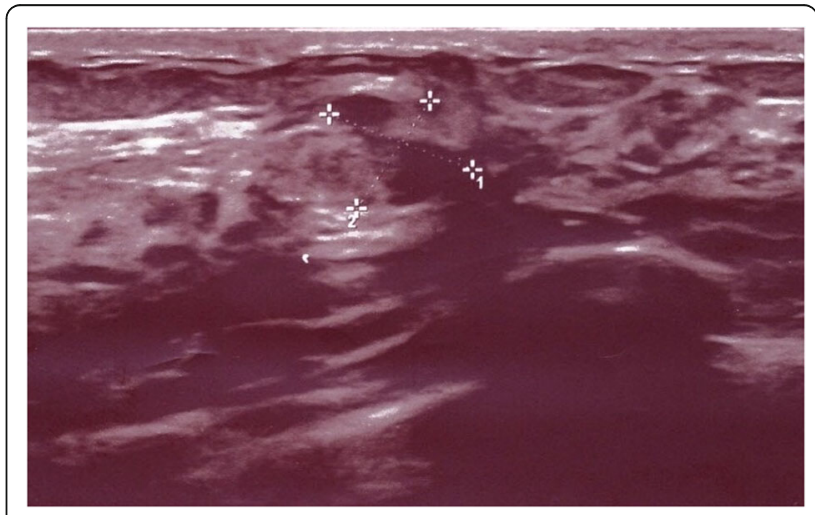

Fig. 1 Patient W.: Mamma-Ca was diagnosed in 2015 


\section{Patient W}

Patient W. was born in 1981 and, in 2015 (Patient W. was 33 y. o.), she developed an invasive ductal MammaCa pT1b pNo (073 sn) M0 V0 L0 G2 Pn0 R0, $4 \times 9$ mm (Fig. 1). The tumour was resected. Chemotherapy (3 weeks primary anti-hormonal therapy with Tamoxifen, 8 cycles Nab-Paclitaxel and 4 cycles Epirubicin/ Cyclophosphamide) was administered. Before beginning of chemotherapy it was detected the pre-menopausal status. Before cryopreservation of ovarian tissue (Patient
W. was 33 y. o., had body length $165 \mathrm{~cm}$ and weight 58 $\mathrm{kg}$, BMI =22) and beginning of anticancer treatment it was detected the idiopathic ovarian insufficiency (low ovarian reserve of unknown cause) of Patient W.: $56 \mathrm{IU} / \mathrm{l}$ FSH, $8 \mathrm{ng} / \mathrm{l} \quad \beta$-estradiol, $<1.1 \mathrm{ng} / \mathrm{ml}$ anti-Müllerian hormone.

From Patient W. it was obtained informed consent. Freezing of the ovarian tissue of Patient W. was performed as described above. Ovarian tissue was removed from the left ovary, and the right ovary was intact. After
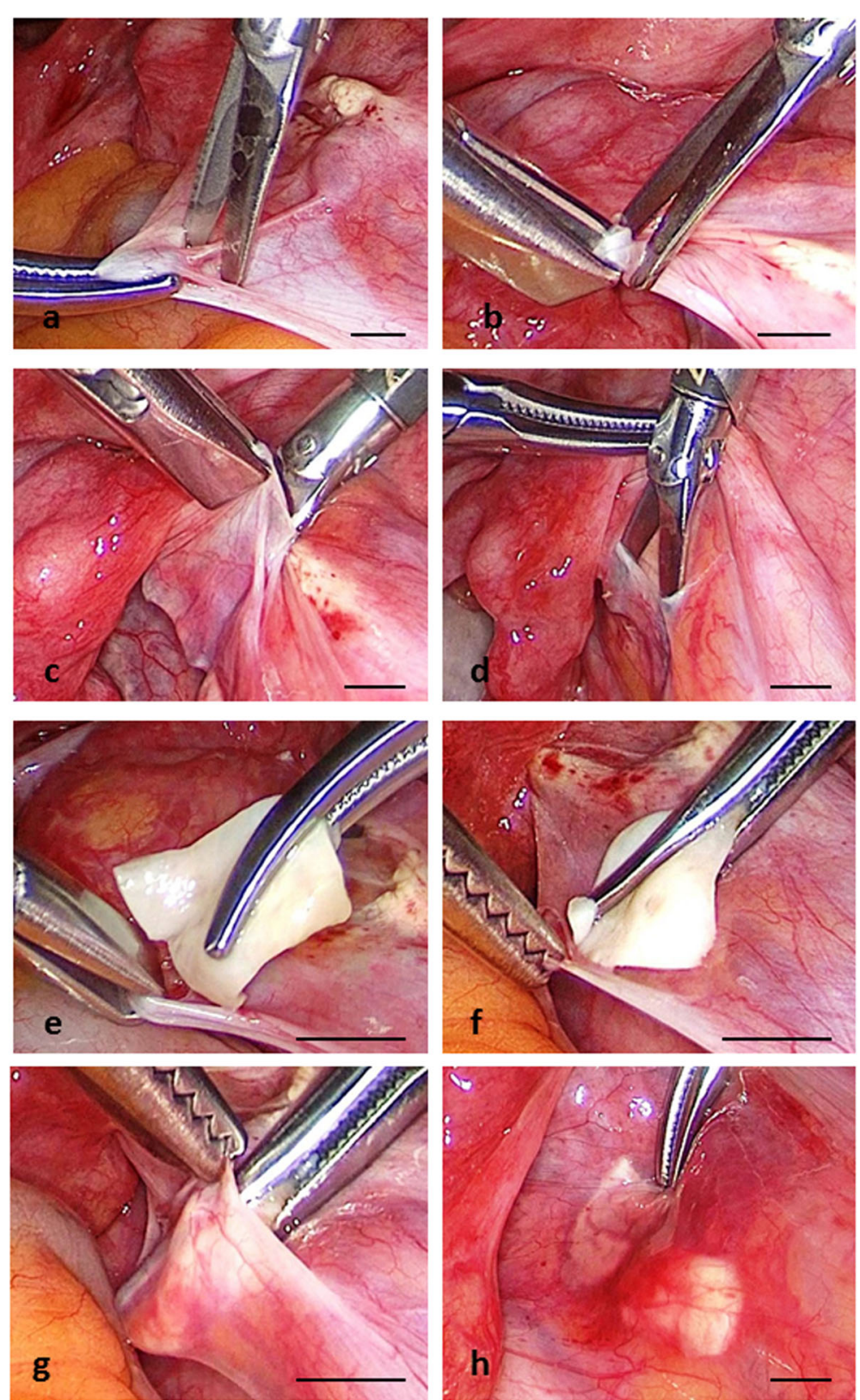

Fig. 2 Transplantation of frozen ovarian tissue of Patient W. in 2019. a, b, c, d Formation of two separated peritoneal windows. e, $\mathbf{f}$, $\mathbf{g}$ Insertion of two thawed ovarian fragments into two peritoneal windows. $\mathbf{h}$ Two ovarian fragments in two separated peritoneal windows on then end of transplantation. Bar $=5.0 \mathrm{~mm}$ 


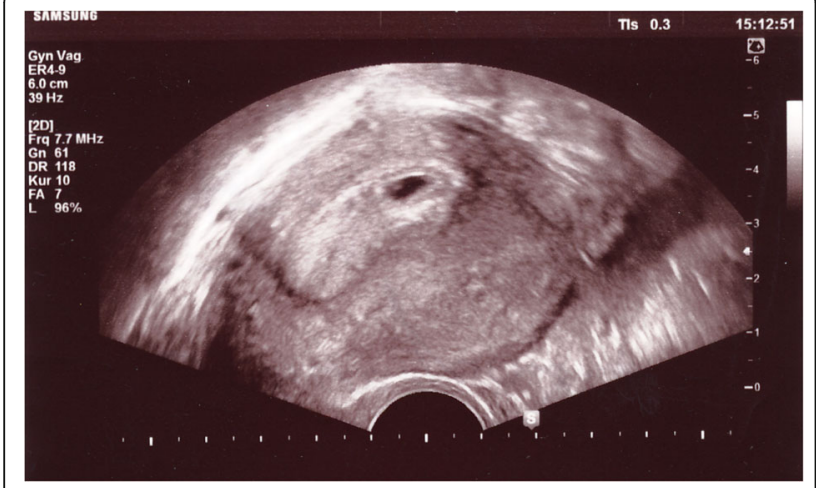

Fig. 3 Spontaneous pregnancy of Patient W. 3 months after retransplantation of ovarian tissue: ultrasound showing 3 week pregnancy

partial removal of the medulla, it was formed four ovarian fragments $(10-16 \times 8-13 \times 1.0-1.2 \mathrm{~mm})$ and these fragments were frozen ( 4 cryo-vials for 4 fragments and 2 cryo-vials for 10 experimental pieces). In 2019, 4 years after the end of anticancer treatment (Patient W. was 37 y. o.), $25 \%$ of the ovarian tissue ( 1 of 4 cryo-vials) was thawed. Ovarian fragment was cut into two parts $(8 \times$ $7 \times 1.0 \mathrm{~mm}$ and $7 \times 6 \times 1.0 \mathrm{~mm})$ and re-transplantated in the peritoneal window on the left side (Fig. 2).

Thirty seven days after the re-transplantation of ovarian tissue, the restoration of the menstrual cycle of Patient W. was noted.
After 7 days of in vitro culture, the experimental ovarian pieces were observed to have developed a spherical shape. It was histologically evaluated $5 \mathrm{~mm}^{3}$ from $10 \mathrm{~mm}^{3}$ of tissue. It was found one primary follicle of good quality.

Three months after the autotransplantation Patient W. became spontaneously pregnant (Fig. 3) and later delivered a healthy baby girl $(3370 \mathrm{~g})$ at term.

\section{Discussion and conclusion}

In accordance with concept of our cryobank, prior to the freezing of ovarian tissue, immature follicles should be punctured to obtain GV-oocytes. Also in the process of preparation of four fragments (cutting of tissue and partial removal of medulla, we obtain spontaneously a number of GV-oocytes. Cryopreservation of both ovarian cortex and oocytes offers the possibility of "doublefertility preservation" [12]. Just after the end of fragments preparation, we check the bottom of Petri dish, collect GV-oocytes (oocytes cumulus complexes) for following maturation to MII stage and cryopreservation (vitrification). From patient it is possible to obtain as many as 20 good quality GV-oocytes (Fig. 4a as example). After the respective manipulations with ovarian tissue of Patient W., we have found two GV-oocytes. These oocytes were matured to MII stage, cryopreserved and fertilized after warming. One normal and one degenerated derived embryos (all in vitro cultured oocytes must be transferred independently from the
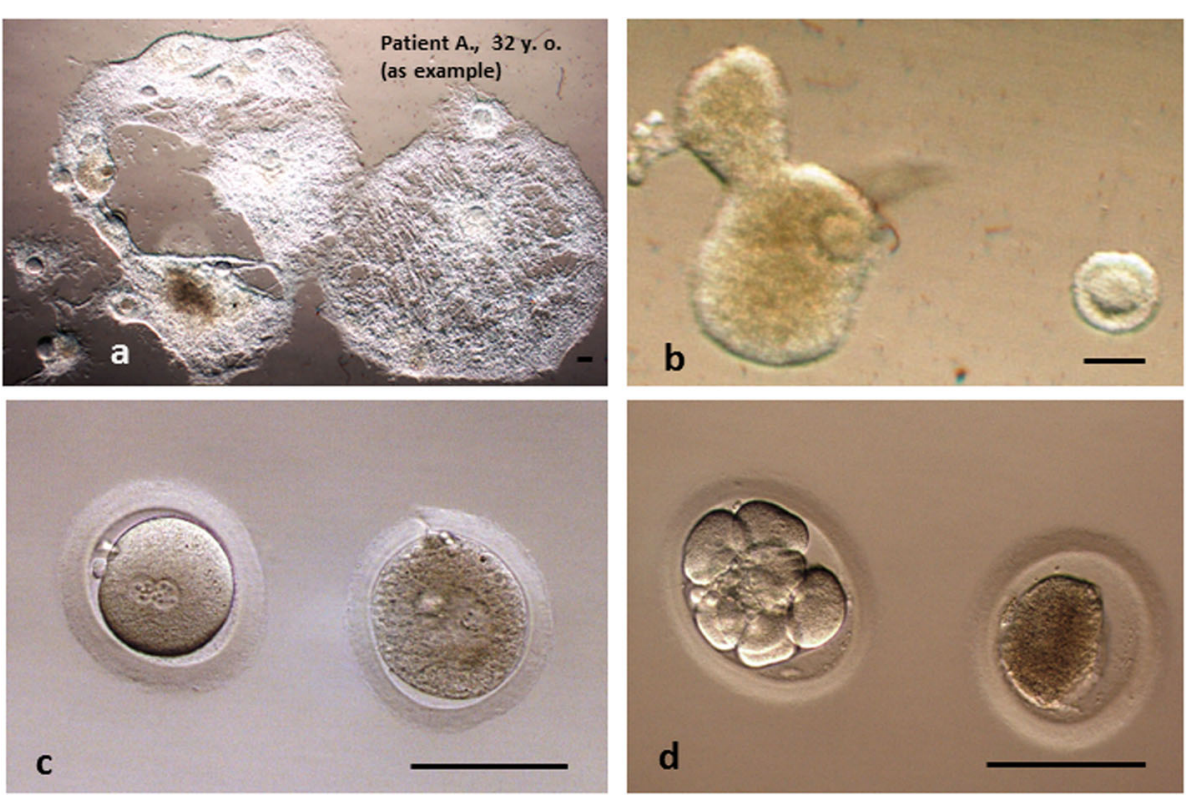

Fig. 4 Embryos of Patient W. obtained after preparation of ovarian fragments. a Comparative example of a pool of GV-oocytes obtained after preparation of ovarian tissue from another patient after in vitro maturation to M-II stage (29 h). b GV-oocytes before in vitro maturation to M-II stage (28 h) and cryopreservation (vitrification). c PN-embryos after warming of M-II oocytes and ICSI. d Three-days normal embryo and degenerated oocyte before transfer 
developmental stage) were transplanted (Fig. 4 b, c, d). No implantation was noted. The aim of mentioned above is additionally to show the low number of obtained GV-oocytes that can be explained by the low ovarian reserve of Patient W.

It is known that primordial follicles in premature ovarian failure (POF) patients cannot be activated normally, and mature oocytes cannot be obtained for in vitro fertilization [13]. However, in vitro activation (IVA) of primordial follicles, allows them to grow to a developed stages [3, 14]. IVA technology offers a new potential treatment for such patients [14-16].

IVA procedure exists in form of drug-included [17-19] as well as drug-free [20-24] treatments.

Drug-free activation can be realized in different forms, such as scraping [24], biopsy [21, 23], sectioning [22, 23]. Hippo signaling pathway is an important intracellular signaling pathway that plays an important role in controlling cell proliferation and determining tissue size, and it is conserved in all multicellular animals [25]. All drug-free treatments include destructive manipulations with ovarian tissue and probably include the interruption of ovarian Hippo signaling expenses.

It has been reported that fragmentation of ovaries induced a transient increase in the polymerization of Gactin to F-actin, decreases in phospho-YAP levels, and increases in nuclear localization of YAP [26]. Our protocol of preparation of ovarian fragments from Patient W. includes scarification and shredding of tissue. By opinion of Kawamura et al. [26], shredded ovarian tissue may be available for Hippo signal activation in our case.

We offer the following hypothesis which can explain the effectivity of retransplantation of ovarian tissue of Patient W. with very low ovarian reserve. Fact is that at least five negative effects observed during cells cryopreservation: hypoxia, increasing of intracellular $\mathrm{Ca}^{2+}$, osmotic disruption of cellular membranes, generation of reactive oxygen species (ROS) and lipid peroxidation. Each from these factors can lead to the interruption of ovarian Hippo signaling expenses. By this fact can be explain a positive effect of cryopreservation on the following development of follicles. In that case, we offer to evaluate the cryopreservation procedure of ovarian tissue as in vitro activation of follicles. Certainly, the aim of cryopreservation of ovarian tissue is storage of cells function after thawing. For this purpose we offer the cryopreservation technology described here.

In conclusion, described protocol of conventional cryopreservation of ovarian tissue can be used for treatment of patients with ovarian insufficiency.

\section{Abbreviations}

IU: international units; FSH: follicle stimulations hormone; LH: luteinizing hormone; BMI: Body mass index; YAP: Yes-associated protein

\section{Acknowledgements}

The authors are very grateful to Ms. Peters, Mr. Karbassian, Ms. Hilger for technical assistance. Authors are grateful Patient W. for all information presented after birth of child and nice photographs of her daughter.

\begin{abstract}
Authors' contributions
Conceived and designed the experiments: V.I., B.M., P.T., E.I., B.H., G.R., performed the experiments: V.I., E.I., P.T., B.M., analyzed the data: G.R., P.M., contributed reagents/materials/analysis tools: B.M., P.M., G.R., wrote the manuscript: V.I., E.I., G.R., P.T., manuscript drafting and critical discussion: V.I., B.M., P.T., E.I., P.M., B.H., G.R., finally approved of the version to be published: V.I. P.M. The author(s) read and approved the final manuscript
\end{abstract}

\section{Authors' information}

Addition author's information is available on

https://frauenklinik.uk-koeln.de/forschung/ag-reproduktionsmedizin/researchgroup-for-reproductive-medicine/

http://frauenklinik.uk-koeln.de/reproduktionsmedizin-kryokonservierung https://frauenklinik.uk-koeln.de/klinik/direktor-team/

https://invitro.bg/en/about-us/

\section{Funding}

Open Access funding enabled and organized by Projekt DEAL.

\section{Availability of data and materials}

Full availability of data and material are declared. Also the datasets used and/or analyzed during the current study are available from the corresponding author on reasonable request.

Ethics approval and consent to participate

This study was approved by the Ethics Boards of University Cologne (applications 99184 and 13-147). Written informed consents were obtained from participant involved in our study.

\section{Consent for publication}

Not applicable.

\section{Competing interests}

The authors declare that they have no competing of interest.

\section{Author details}

'Department of Obstetrics and Genecology, University Maternal Hospital, Research Group for Reproductive Medicine and IVF-Laboratory, Cologne University, Cologne, Germany. ${ }^{2}$ Institute of Biology and Immunology of Reproduction, Sofia, Bulgaria.

Received: 5 August 2020 Accepted: 8 September 2020

Published online: 29 September 2020

\section{References}

1. Siegel RL, Miller KD, Jemal A. Cancer statistics, 2020. CA Cancer J Clin. 2020; 70:7-30.

2. von Wolff M, Donnez J, Hovatta O, Keros V, Maltaris T, Montag M, et al. Cryopreservation and autotransplantation of human ovarian tissue prior to cytotoxic therapy-a technique in its infancy but already successful in fertility preservation. Eur J Cancer. 2009;45:1547-53.

3. Donnez J, Dolmans MM. Fertility preservation in women. N Engl J Med. 2017;377:1657-65. https://doi.org/10.1056/NEJMra1614676.

4. Isachenko V, Isachenko E, Mallmann P, Rahimi G. Increasing follicular and stromal cell proliferation in cryopreserved human ovarian tissue after longterm precooling prior to freezing: in vitro versus chorioallantoic membrane (CAM) xenotransplantation. Cell Transplant. 2013;22:2053-61.

5. Isachenko V, Todorov P, Isachenko E, Rahimi G, Tchorbanov A, Mihaylova N, et al. Long-time cooling before cryopreservation decreased translocation of Phosphatidylserine (Ptd-L-Ser) in human ovarian tissue. PLoS One. 2015;10: e0129108

6. Isachenko V, Isachenko E, Reinsberg J, Montag M, van der Ven K, Dorn C, et al. Cryopreservation of human ovarian tissue: comparison of rapid and conventional freezing. Cryobiology. 2007;55:261-8.

7. Isachenko V, Lapidus I, Isachenko E, Krivokharchenko A, Kreienberg R, Woriedh $\mathrm{M}$, et al. Vitrification and conventional freezing of human ovarian 
tissue: morphological, endocrinological and molecular biological evaluation. Reproduction. 2009;138:319-27.

8. Isachenko V, Todorov P, Isachenko E, Rahimi G, Hanstein B, Salama M, et al. Cryopreservation and xenografting of human ovarian fragments: medulla decreases the phosphatidylserine translocation rate. Reprod Biol Endocrinol. 2016;14:79.

9. Isachenko V, Isachenko E, Reinsberg J, Montag M, Weiss J, et al. Simplified technique of human ovarian tissue freezing: quick cooling from $-36^{\circ} \mathrm{C}$. Cryo Letters. 2008;29:261-8.

10. Isachenko V, Isachenko E, Weiss JM, Todorov P, Kreienberg R. Cryobanking of human ovarian tissue for anti-cancer treatment: comparison of vitrification and conventional freezing. Cryo Letters. 2009:30:449-54.

11. Isachenko V, Morgenstern TP, Isachenko E, Mallmann P, Hanstein B, et al. Long-term (24h) cooling of ovarian fragments in the presence of permeable Cryoprotectants prior to freezing: two Unsuccesful IVF-cycles and spontaneous pregnancy with baby born after re-transplantation. Cryobiology. 2020;93:115-20.

12. Isachenko $E$, Gohar $R$, Isachenko $V$, Nawroth F. In-vitro maturation of germinal vesicle oocytes and cryopreservation in metaphase I/ll: a possible addition option to preserve fertility during ovarian tissue cryopreservation. Reprod BioMed Online. 2004;8:553-7.

13. De Vos M, Devroey P, Fauser BC. Primary ovarian insufficiency. Lancet. 2010; 376:911-21. https://doi.org/10.1016/s0140-6736(10)60355-8.

14. Li J, Kawamura K, Cheng Y, Liu S, Klein C, Liu S, et al. Activation of dormant ovarian follicles to generate mature eggs. Proc Natl Acad Sci U S A. 2010; 107:10280-4. https://doi.org/10.1073/pnas.1001198107.

15. Reddy P, Liu L, Adhikari D, Jagarlamudi K, Rajareddy S, Shen Y, et al. Oocytespecific deletion of Pten causes premature activation of the primordial follicle pool. Science. 2008;319:611-3. https://doi.org/10.1126/science. 1152257.

16. Lan C, Xiao W, Xiao-Hui D, Chun-Yan H, Hong-Ling Y. Tissue culture before transplantation of frozen-thawed human fetal ovarian tissue into immunodeficient mice. Fertil Steril. 2010;93:913-9. https://doi.org/10.1016/j. fertnstert.2008.10.020.

17. Kawamura K, Cheng Y, Suzuki N, Deguchi M, Sato Y, Takae S, et al. Hippo signaling disruption and Akt stimulation of ovarian follicles for infertility treatment. Proc Natl Acad Sci U S A. 2013;110:17474-9. https://doi.org/10. 1073/pnas.1312830110

18. Suzuki N, Yoshioka N, Takae S, Sugishita Y, Tamura M, Hashimoto S, et al. Successful fertility preservation following ovarian tissue vitrification in patients with primary ovarian insufficiency. Hum Reprod. 2015;30:608-15. https://doi.org/10.1093/humrep/deu353.

19. Zhai J, Yao G, Dong F, Bu Z, Cheng Y, Sato Y, et al. In vitro activation of follicles and fresh tissue auto-transplantation in primary ovarian insufficiency patients. J Clin Endocrinol Metab. 2016;101:4405-12. https://doi.org/10.1210/ jc.2016-1589.

20. Fabregues F, Ferreri J, Calafell JM, Moreno V, Borras A, Manau D, et al. Pregnancy after drug-free in vitro activation of follicles and fresh tissue autotransplantation in primary ovarian insufficiency patient: a case report and literature review. J Ovarian Res. 2018;11:76. https://doi.org/10.1186/ s13048-018-0447-3.

21. Zhang X, Han T, Yan L, Jiao X, Qin Y, Chen Z-J. Resumption of ovarian function after ovarian biopsy/scratch in patients with premature ovarian insufficiency. Reprod Sci. 2018;26:193371911881890. https://doi.org/10.1177/ 1933719118818906.

22. Kawamura K, Ishizuka B, Hsueh AJW. Drug-free in-vitro activation of follicles for infertility treatment in poor ovarian response patients with decreased ovarian reserve. Reprod BioMed Online. 2020;40:245-53. https://doi.org/10. 1016/j.rbmo.2019.09.007.

23. Ferreri J, Fabregues F, Calafell JM, Solernou R, Borras A, Saco A, et al. Drugfree in-vitro activation of follicles and fresh tissue autotransplantation as a therapeutic option in patients with primary ovarian insufficiency. Reprod BioMed Online. 2020;40:254-60. https://doi.org/10.1016/j.rbmo.2019.11.009.

24. Lunding SA, Pors SE, Kristensen SG, Landersoe SK, Jeppesen JV, Flachs EM, et al. Biopsying, fragmentation and autotransplantation of fresh ovarian cortical tissue in infertile women with diminished ovarian reserve. Hum Reprod. 2019;34:1924-36. https://doi.org/10.1093/humrep/dez152.

25. Halder G, Johnson RL. Hippo signaling: growth control and beyond. Development. 2011;138:9-22. https://doi.org/10.1242/dev.045500.
26. Kawamura K, Kawamura N, Hsueh AJ. Activation of dormant follicles: a new treatment for premature ovarian failure? Curr Opin Obstet Gynecol. 2016;28: 217-22. https://doi.org/10.1097/GCO.0000000000000268.

\section{Publisher's Note}

Springer Nature remains neutral with regard to jurisdictional claims in published maps and institutional affiliations.
Ready to submit your research? Choose BMC and benefit from:

- fast, convenient online submission

- thorough peer review by experienced researchers in your field

- rapid publication on acceptance

- support for research data, including large and complex data types

- gold Open Access which fosters wider collaboration and increased citations

- maximum visibility for your research: over $100 \mathrm{M}$ website views per year

At BMC, research is always in progress.

Learn more biomedcentral.com/submissions 